\title{
A fast exploration of very deep soil layers by Eucalyptus seedlings and clones in Brazil
}

\author{
Rafael Costa Pinheiro a , José Carlos de Deus Jr. ${ }^{a}$, Yann Nouvellon ${ }^{\mathrm{b}, c}$, Otávio Camargo Campoe ${ }^{\mathrm{d}}$, \\ José Luiz Stape ${ }^{\mathrm{e}}$, Lívia Lanzi Aló ${ }^{\mathrm{f}}$, Iraê Amaral Guerrini ${ }^{\mathrm{a}}$, Christophe Jourdan ${ }^{\mathrm{b}}$, Jean-Paul Laclau ${ }^{\mathrm{a}, \mathrm{b}, *}$ \\ a Departamento de Solos e Recursos Ambientais, Universidade Estadual Paulista 'Júlio de Mesquita Filho', CEP 18610-300 Botucatu, São Paulo, Brazil \\ ${ }^{\mathrm{b}}$ CIRAD, UMR EcoESSols, 2 Place Viala, 34060 Montpellier, France \\ ${ }^{\mathrm{C}}$ Universidade de São Paulo, Departamento de Ciências Atmosféricas, CEP 05508-900 São Paulo, Brazil \\ ${ }^{\mathrm{d}}$ Forestry Science and Research Institute - IPEF, CEP 13418-260 Piracicaba, São Paulo, Brazil \\ ${ }^{\mathrm{e}}$ Department of Forestry and Environmental Resources, North Carolina State University, Raleigh, NC 27695-8008, USA \\ ${ }^{\mathrm{f}}$ Centro de Ciências e Tecnologias para Sustentabilidade, Universidade Federal de São Carlos, CEP 18052-780 Sorocaba, São Paulo, Brazil
}

\section{A R T I C L E I N F O}

\section{Article history:}

Received 11 November 2015

Received in revised form 7 February 2016

Accepted 9 February 2016

Available online 17 February 2016

\section{Keywords:}

Eucalypt

Fine root

Breeding

Leaf area

Root area

Tropical soil

\begin{abstract}
A B S T R A C T
Although pioneer studies showed several decades ago that deep rooting is common in tropical forests, direct measurements of fine root distributions over the entire soil profile explored by the roots are still scarce. Our study aimed to compare, 2 years after planting, fine root traits of Eucalyptus trees planted from cuttings and from seedlings in order to assess whether the propagation mode has an influence on the capacity of the trees to explore very deep soils. Soils cores were sampled down to a depth of $13.5 \mathrm{~m}$ at the peak of leaf area index (LAI), 2 years after planting, under three Eucalyptus clones (belonging to species E. saligna, E. grandis $\times E$. urophylla, E. grandis $\times E$. camaldulensis) and under E. grandis seedlings in the same Ferralsol soil. LAI was estimated using allometric equations based on destructive sampling of eight trees per genotype.

All the genotypes exhibited fine root densities roughly constant between the depths of 0.25 and $6.00 \mathrm{~m}$. Changes in fine root traits (diameter, specific root length and specific root area) were low between the topsoil and the root front. The ratios between mean tree height and root front depth ranged from 0.8 to 1.2 for the four genotypes. Although tree vertical extension was roughly symmetric above and belowground for all the genotypes, the depth of the root front ranged from $8.0 \mathrm{~m}$ for the seedlings and the E. grandis $\times$ E. urophylla clone to $11.5 \mathrm{~m}$ for the E. saligna clone. Soil water content profiles suggested that the four genotypes had the capacity to withdraw water down to a depth of 8-10 m over the first 2 years after planting. Total fine root length ranged from 3.3 to $6.0 \mathrm{~km}$ per $\mathrm{m}^{2}$ of soil depending on the genotype. The root area/leaf area ratio ranged from 1.3 to 3.2 and was negatively correlated with LAI across the four genotypes. This pattern suggests that the genotypes more conservative for water use (with a low LAI) invest more in fine root area relative to leaf area than genotypes adapted to wet regions (with a high LAI). The velocity of downward movement of the root front might be a relevant criterion in the last stage of the breeding programs to select clones with a fast exploration of deep soil layers in drought prone regions.
\end{abstract}

(c) 2016 Elsevier B.V. All rights reserved.

\section{Introduction}

The major role of deep roots to supply water and nutrients in tropical forests has been pointed out for several decades (e.g. Nepstad et al., 1994; Schenk and Jackson, 2002a), however, studies quantifying fine root distributions below a depth of $3 \mathrm{~m}$ remain

* Corresponding author at: CIRAD, UMR Eco\&Sols, 2 Place Viala, 34060 Montpellier, France.

E-mail address: laclau@cirad.fr (J.-P. Laclau). scarce (Maeght et al., 2013; Freycon et al., 2015). The processes controlling water and nutrient uptake in very deep soil layers are still poorly understood in forest ecosystems and require further attention (Iversen, 2010; Binkley, 2015). The comparisons of measured (with the eddy-covariance technique) and modeled evapotranspiration across forests and savannas in Africa and Amazonia showed that the rooting depth is a major variable controlling the predictions of evapotranspiration during dry seasons in soil-vegetationatmosphere-transfer (SVAT) models (Akkermans et al., 2012; Christoffersen et al., 2014). These studies suggest that the biological 
processes driving root dynamics in deep soil layers and leaf phenology should be urgently investigated, since these mechanisms mediate vegetation-climate feedbacks in the tropics through their control on evapotranspiration.

Simple forest ecosystems like Eucalyptus plantations can contribute to improving our understanding of the belowground strategy of fast-growing trees. Eucalyptus plantations are rapidly expanding in tropical regions and cover nowadays approximately 20 million ha worldwide (Grant et al., 2012; Booth, 2013). The area of these fast-growing plantations in Brazil shifted from 3.4 million ha in 2005 to 5.6 million ha in 2014 (ABRAF, 2006; IBÁ, 2015 ), which represents about $25 \%$ of the total area of eucalypt plantations in the world and almost $70 \%$ of the planted forests in Brazil. A recent study in a deep tropical soil showed that the maximum rooting depth of Eucalyptus grandis seedlings managed in short-rotation plantations was close to the mean stand height from planting to harvesting (Christina et al., 2011). However, the architecture of root systems is highly dependent on propagation techniques (seedlings vs cuttings) and genotypes (Fensham and Fairfax, 2007; Nibau et al., 2008; Bonneu et al., 2012), and most of the commercial plantations are now established with clones of several Eucalyptus species. Therefore, the relationship between stand height and maximum rooting depth observed for E. grandis seedlings might be different for the highly productive clones planted nowadays at large scale in tropical regions. Fertilization regimes are designed to supply tree nutrient requirements in commercial eucalypt plantations and the productivity is generally limited by water availability (du Toit et al., 2010; Stape et al., 2010). The root front velocity might be a relevant trait to consider in breeding programs of eucalypt species since an eventual access to the water table may explain different growth and survival rates between clones in exceptionally dry periods (Harper et al., 2009; Decker et al., 2013; Poot and Veneklaas, 2013; Matusick et al., 2013; Zolfaghar et al., 2014). Clones with deep roots may have access to a larger amount of water stored in deep soil layers compared to genotypes with a more superficial root distribution. Recent studies in Australian (Robinson et al., 2006; Mendham et al., 2011; Harper et al., 2014) and Brazilian eucalypt plantations (Battie-Laclau et al., 2014) showed that fine roots at depths $>5 \mathrm{~m}$ can have an important functional role to supply water for tree growth during drought periods. Fine root traits are very challenging to measure (Maeght et al., 2013) and therefore cannot be used to screen a large number of genotypes. However, forest companies use a small number of new clones annually (commonly half a dozen) and the root front velocity of each clone planted at large scale might be an interesting criterion to measure in clonal tests at the last stage of the breeding programs. This basic information might be relevant to improve the matching between the root traits of each clone and the characteristics of the planting areas (in particular drought risk and soil depth).

Exploration of deep soil layers can have an important metabolic cost for plants (Iversen, 2010). Genotypes maximizing fine root length and fine root area for a given investment in belowground biomass are likely to improve water and nutrient acquisition. Fast growth requires fast and efficient acquisition both of above and belowground resources, and thus fast-growing and invasive tree species generally have higher specific root area (SRA), specific root length (SRL), smaller root diameter, and higher specific leaf area (SLA) than slow-growing species (Reich, 2014; Jo et al., 2015). Despite the growing body of evidence that deep roots can play a major role in functional ecology for a broad range of terrestrial ecosystems, studies investigating the changes in fine root traits between the topsoil and soil layers at depths $>3 \mathrm{~m}$ remain scarce (Roupsard et al., 1999; Maeght et al., 2013). Insufficient sampling depths in many studies contributed to underestimates of actual rooting depths, especially in tropical forests (Schenk and Jackson, 2002b). Water and nutrient availabilities in tropical eucalypt plantations strongly change with depth in the soil (e.g. Mareschal et al., 2013; Versini et al., 2014), which might lead to contrasting suites of traits with depth since root traits are highly responsive to heterogeneous resource distributions (Ostonen et al., 2007; Prieto et al., 2015).

Fine root distributions cannot be measured for a large number of genotypes in deep soil layers and indicators of soil exploration by fine roots would be useful in breeding programs for a rapid screening of genotypes adapted to seasonally dry areas and to coarse-textured soils with low water retention capacity (Hamer et al., 2015). Leaf and fine root areas are hydraulically interdependent, thus constraining trees to adjust their area of water uptake to their area of water loss (Magnani et al., 2002; Zeppel, 2013; Mackay et al., 2015). Strong relationships between leaf biomass and fine root biomass have been shown throughout the early growth of Eucalyptus globulus (O'Grady et al., 2006) and E. grandis plantations (Laclau et al., 2008). A positive correlation between root area index (RAI) and leaf area index (LAI) was found across five poplar clones (Al Afas et al., 2008). However, the root area to leaf area ratio, or the root length to leaf area ratio were reported to vary depending on stand age (O'Grady et al., 2006), soil water availability (Rhizopoulou and Davies, 1993; Costa e Silva et al., 2004; Martin-StPaul et al., 2013), and genotype (Costa e Silva et al., 2004; Hamer et al., 2015). A modeling approach suggested that the root area to leaf area ratio (RAI/LAI) should be higher for anisohydric species than for isohydric species (Mackay et al., 2015). This ratio is therefore likely to greatly vary among eucalypt species growing in the same environment, with lower values for species from wet regions than for species from dry regions (Hamer et al., 2015).

Our study aimed to compare, two years after planting, fine root traits of Eucalyptus trees planted from cuttings and from seedlings in order to assess whether the propagation mode has an influence on the capacity of the trees to explore very deep soils. We hypothesized that: (i) the genotypes with the highest growth rates exhibit the highest SRL and SRA values, (ii) the pattern of exploration of deep soil layers is similar for seedlings and clones at the peak of LAI (2 years after planting) with an almost symmetrical vertical tree extension above and belowground, and (iii) the genotypes with the lowest LAI, presumably more conservative for wateruse, have the highest root area to leaf area ratio. Although the range of productivity of the genotypes used in our study was narrow relative to the diversity of growth rates of eucalypt species and hybrids planted worldwide, we studied genotypes representative of the range of production observed in Brazilian eucalypt plantations. As far as we are aware, this study is the first investigating major fine root traits (root front velocity as well as fine root diameter, specific root length and specific root area) down to the root front at depths $>10 \mathrm{~m}$ for genotypes propagated by cuttings in tropical planted forests.

\section{Material and methods}

\subsection{Study site}

Our study was carried out in commercial Eucalyptus plantations managed by the EucFlux project (http://www.ipef.br/eucflux/en/) at Itatinga $\left(22^{\circ} 58^{\prime} 04^{\prime \prime} \mathrm{S}, 48^{\circ} 43^{\prime} 40^{\prime \prime} \mathrm{W}\right)$ in southeast Brazil (São Paulo State). Annual rainfall at the study site was $1278 \mathrm{~mm}$ in 2010 and $1758 \mathrm{~mm}$ in 2011 ( $\sim 90 \%$ concentrated from October to May) and mean annual temperature was $19.5^{\circ} \mathrm{C},\left(16.3^{\circ} \mathrm{C}\right.$ on average from June to August and $22.2^{\circ} \mathrm{C}$ on average from December to February). The mean annual air relative humidity was $76 \%$, with minimum values of $\sim 30 \%$ between July and September. 
The soils were deep Ferralsols (FAO classification), developed on Cretaceous sandstone of the Marilia formation, Bauru group. The relief was typical of the São Paulo Western Plateau, with a gently undulating topography. The slope was $<5 \%$, and the maximum elevation was $760 \mathrm{~m}$ above sea level. Soil properties were representative of the most common soil type where eucalypt plantations are established in Brazil (Table 1). Clay contents ranged from about $16 \%$ in the topsoil to $22-25 \%$ in the $2-10 \mathrm{~m}$ soil layer. Whatever the soil layer down to a depth of $14 \mathrm{~m}$, soil $\mathrm{pH}_{\mathrm{CaCl} 2}$ was approx. 4 and the concentrations of nutrients were approx. $5 \mathrm{mg} \mathrm{kg}^{-1}$ for $P_{\text {resin }}$ and $6 \mathrm{mmol}_{\mathrm{c}} \mathrm{kg}^{-1}$ for the sum of base cations (exch. $\mathrm{K}^{+}, \mathrm{Ca}^{2+}$ and $\mathrm{Mg}^{2+}$ ). The monitoring of the water table at approx. $500 \mathrm{~m}$ from our experiment showed that the depth decreased by $6 \mathrm{~m}$ the first 1.5 years after clear-cutting the previous stand, then slowly increased over the rotation (unpublished data). Soil coring down to a depth of $13.5 \mathrm{~m}$ in the present study and down to $17 \mathrm{~m}$ in the same plots 4 years after planting (data not shown) suggested that the water table was at a depth of approximately 14-15 m when our study was carried out. The mineralogy was dominated by quartz, kaolinite and oxyhydroxides (Maquère, 2008).

\subsection{Experimental design}

Our study was carried out in two genotype tests (two blocks) replicated at about $300 \mathrm{~m}$ apart on the same soil type. Four genotypes selected by forest companies for their high growth rates were studied in each test:

Seedlings: seed lot of the E. grandis species used in the past by the Duratex Company in the São Paulo state (mean temperature of $19{ }^{\circ} \mathrm{C}$ and mean annual rainfall of $1340 \mathrm{~mm}$ in the region). These seedlings were less productive than the best clones planted nowadays.

Clone 8: clone of the $E$. grandis $\times E$. urophylla hybrid selected by the Cenibra Company in the Minas Gerais state (mean temperature of $23^{\circ} \mathrm{C}$ and mean annual rainfall of $1380 \mathrm{~mm}$ in the region).

Clone 14: clone of the Eucalyptus saligna species selected by the Klabin Company in the Rio Grande do Sul state (mean temperature of $19^{\circ} \mathrm{C}$ and mean annual rainfall of $1680 \mathrm{~mm}$ in the region).

Clone 16: clone of the $E$. grandis $\times E$. camaldulensis hybrid selected by the Copener Company in the Bahia state (mean temperature of $25^{\circ} \mathrm{C}$ and mean annual rainfall of $700 \mathrm{~mm}$ in the region).

Four Eucalyptus genotypes, three clones of pure species and hybrids as well as one seedling lot (considered here as one "genotype"), were planted (spacing $3 \mathrm{~m} \times 2 \mathrm{~m}$ ) in each genotype test $(12 \times 14$ trees per plot). The three clones were chosen to cover a large range of LAI at 2 years of age (from 2.8 to $4.0 \mathrm{~m}^{2} \mathrm{~m}^{-2}$ ), the range of productivities in commercial plantations and to represent the main species and hybrids currently planted in Brazil. Seedlings were also studied to compare fine root distributions for eucalypt trees propagated via seeds and cuttings. The seedlings were representative of the least productive genotypes still used in commercial plantations in Brazil. The main characteristics of the stands at the sampling age are shown in Table 2. Fertilization regimes used in commercial plantations were applied: $18 \mathrm{~kg} \mathrm{~N} \mathrm{ha}^{-1}, 90 \mathrm{~kg} \mathrm{P}_{2} \mathrm{O}_{5}$ $\mathrm{ha}^{-1}, 30 \mathrm{~kg} \mathrm{~K}_{2} \mathrm{O} \mathrm{ha} \mathrm{C}^{-1}$ and $4 \mathrm{Mg} \mathrm{ha}^{-1}$ of dolomitic lime at planting, $31 \mathrm{~kg} \mathrm{Nha}^{-1}, \quad 36 \mathrm{~kg} \mathrm{~K}_{2} \mathrm{O} \mathrm{ha}^{-1}$ at age 4 months, $31 \mathrm{~kg} \mathrm{~N} \mathrm{ha}^{-1}$, $67 \mathrm{~kg} \mathrm{~K}_{2} \mathrm{O} \mathrm{ha} \mathrm{ha}^{-1}$ at age 12 months and $151 \mathrm{~kg} \mathrm{~K}_{2} \mathrm{O} \mathrm{ha}{ }^{-1}$ at age 24 months. Sulfuramide-based baits $\left(1.3 \mathrm{~kg} \mathrm{ha}^{-1}\right)$ were applied at planting to control ants and weeds were eliminated with glyphosate applications the first year after planting.

\subsection{Fine root sampling}

Fine roots ( $<2 \mathrm{~mm}$ in diameter) of the four genotypes were sampled 2 years after planting, at two distances from the trees in each inner plot (excluding three buffer rows). The two sampling positions in each plot were separated by at least $10 \mathrm{~m}$ of distance. The first sampling position was located in the middle of the interrow (at $1.8 \mathrm{~m}$ from the nearest tree) and the second position was at $0.5 \mathrm{~m}$ from another tree. We sampled a total of four positions for each genotype (two distances from the trees $\times$ two blocks) down to a depth of $13.5 \mathrm{~m}$. We preferred to collect a large number of samples down to the root front than to increase the sampling intensity in the upper soil layers, because previous studies in tropical eucalypt plantations showed that fine root densities do not sharply decrease down to a depth of 3-4 $\mathrm{m}$ at age 2 years. A concentration of fine roots in the upper soil layers occurs only from age 3 years onward in these fast-growing plantations (Bouillet et al., 2002; Laclau et al., 2013a).

Soil cores were sampled in the $0-0.25 \mathrm{~m}$ and $0.25-0.5 \mathrm{~m}$ layers, then every $0.5 \mathrm{~m}$ down to a depth of $13.5 \mathrm{~m}$, using a cylindrical auger with an inner diameter of $9 \mathrm{~cm}$ and a length of $30 \mathrm{~cm}$. We used the same methodology as Christina et al. (2011) to avoid contamination of the soil samples collected at depth by roots from the upper layers. After sampling down to a depth of $2 \mathrm{~m}$, we enlarged the diameter of the hole and we installed a 2 meter-long plastic tube with a diameter of $20 \mathrm{~cm}$ to avoid surface soil falling further down. Only soil blocks from the inner part of the auger were collected and all fragmented soil pieces likely to come from upper soil layers were systematically discarded. Soil samples were put in plastic bags, identified and stored at $4{ }^{\circ} \mathrm{C}$ until processing. The root front was defined at each sampling position as the depth of the layer where the deepest root was observed. Soils were systematically collected a further $2 \mathrm{~m}$ down at each sampling position and the absence of roots below the layer identified as the root front

Table 1

Main physical and chemical soil properties across all the sampling positions in blocks 1 and 2 .

\begin{tabular}{|c|c|c|c|c|c|c|c|c|}
\hline \multirow{2}{*}{$\begin{array}{l}\text { Soil layer } \\
(\mathrm{cm})\end{array}$} & Sand & Silt & Clay & \multirow{2}{*}{$\begin{array}{l}\mathrm{pH} \\
\mathrm{CaCl}_{2} \\
\end{array}$} & \multirow{2}{*}{$\begin{array}{l}\text { O.M. }^{\mathrm{a}} \\
\mathrm{g} \mathrm{kg}^{-1} \\
\end{array}$} & \multirow{2}{*}{$\begin{array}{l}P_{\text {resin }}{ }^{\mathrm{b}} \\
\mathrm{mg} \mathrm{kg}^{-1}\end{array}$} & Base cations $^{\mathrm{b}}$ & \multirow[t]{2}{*}{ CEC } \\
\hline & \multicolumn{3}{|c|}{ Particle size distribution (\%) } & & & & $\mathrm{mmol}_{\mathrm{c}} \mathrm{kg}^{-1}$ & \\
\hline $0-25$ & $80.8 \pm 2.0$ & $3.5 \pm 0.8$ & $15.8 \pm 1.4$ & $3.89 \pm 0.12$ & $13.2 \pm 3.2$ & $4.2 \pm 0.8$ & $6.5 \pm 0.5$ & $51.0 \pm 15.4$ \\
\hline $25-50$ & $79.2 \pm 1.6$ & $3.2 \pm 0.9$ & $17.7 \pm 1.0$ & $4.12 \pm 0.06$ & $8.8 \pm 0.6$ & $4.7 \pm 0.5$ & $5.8 \pm 0.5$ & $34.6 \pm 1.8$ \\
\hline $50-100$ & $77.0 \pm 1.6$ & $4.2 \pm 1.9$ & $18.9 \pm 1.0$ & $4.10 \pm 0.02$ & $7.4 \pm 0.4$ & $4.7 \pm 0.6$ & $5.8 \pm 0.8$ & $29.9 \pm 2.2$ \\
\hline $100-400$ & $71.9 \pm 1.6$ & $4.8 \pm 2.1$ & $23.3 \pm 1.1$ & $4.46 \pm 0.08$ & $7.4 \pm 1.6$ & $4.8 \pm 0.3$ & $6.4 \pm 0.5$ & $22.0 \pm 1.0$ \\
\hline $400-800$ & $67.3 \pm 1.0$ & $8.0 \pm 4.1$ & $24.7 \pm 3.2$ & $4.61 \pm 0.12$ & $4.7 \pm 0.6$ & $5.1 \pm 0.6$ & $6.4 \pm 1.3$ & $19.2 \pm 1.6$ \\
\hline $800-1200$ & $69.2 \pm 1.9$ & $9.1 \pm 4.4$ & $21.7 \pm 3.1$ & $4.37 \pm 0.12$ & $4.5 \pm 0.2$ & $4.5 \pm 0.3$ & $6.2 \pm 0.3$ & $21.0 \pm 5.4$ \\
\hline $1200-1400$ & $82.0 \pm 8.6$ & $4.1 \pm 1.6$ & $14.0 \pm 7.1$ & $4.39 \pm 0.04$ & $4.1 \pm 0.3$ & $4.8 \pm 0.7$ & $5.9 \pm 0.8$ & $15.4 \pm 1.1$ \\
\hline
\end{tabular}

${ }^{a}$ Organic matter (O.M.) determined using sodium dichromate.

b The methodology described by van Raij et al. (2001) was used for resin extraction of phosphorus and exchangeable element determinations. 
Table 2

Main characteristics of the stands at 2 years of age (the values in blocks 1 and 2 are given between parenthesis).

\begin{tabular}{|c|c|c|c|c|}
\hline & $\begin{array}{l}\text { Seedlings } \\
\text { E. grandis }\end{array}$ & $\begin{array}{l}\text { Clone } 8 \\
\text { E. grandis } \times \text { E. urophylla }\end{array}$ & $\begin{array}{l}\text { Clone } 14 \\
\text { E. saligna }\end{array}$ & $\begin{array}{l}\text { Clone } 16 \\
\text { E. grandis } \times \text { E. camaldulensis }\end{array}$ \\
\hline Stocking density (trees $\mathrm{ha}^{-1}$ ) & $1406(1476-1337)$ & $1641(1632-1649)$ & $1606(1615-1597)$ & $1658(1649-1666)$ \\
\hline Stand basal area $\left(\mathrm{m}^{2} \mathrm{ha}^{-1}\right)$ & $8.5(8.9-8.2)$ & $10.6(10.2-11.0)$ & $9.0(8.5-9.5)$ & $11.0(10.1-11.9)$ \\
\hline Trunk biomass ( $\left.\mathrm{Mg} \mathrm{ha}^{-1}\right)$ & $16.4(17.1-15.6)$ & $22.1(21.1-23.0)$ & $19.3(17.8-20.8)$ & $26.4(24.0-28.7)$ \\
\hline Woody production (Mg ha $\left.{ }^{-1} \mathrm{y}^{-1}\right)$ & $8.2(8.6-7.8)$ & $11.0(10.5-11.5)$ & $9.7(8.9-10.4)$ & $13.2(12.0-14.4)$ \\
\hline Dominant height $(\mathrm{m})$ & $11.7(12.0-11.4)$ & $12.0(12.1-11.9)$ & $10.6(10.4-10.8)$ & $11.9(11.7-12.0)$ \\
\hline Mean height (m) & $8.5(8.9-8.0)$ & $10.8(10.6-10.9)$ & $9.5(9.2-9.8)$ & $11.1(10.8-11.4)$ \\
\hline
\end{tabular}

was checked. The absence of any physical or chemical barrier to root growth down to a depth of $13.5 \mathrm{~m}$ was checked at all the sampling positions in our experiment.

Soil samples collected in the field were weighed and uniformly mixed. Gravimetric soil water contents were measured in each soil sample from $20 \mathrm{~g}$ of soil dried at $105^{\circ} \mathrm{C}$ up to constant weight. All the fine roots in the samples were washed free of soil with tap water using sieves (with mesh sizes from 0.50 to $1.19 \mathrm{~mm}$ ) and all the living roots with a length $>1 \mathrm{~cm}$ were separated carefully by hand. Living roots were sorted using criteria such as a living stele, bright color and flexibility. A sub-sample (10\% of the weight of each soil sample) was used to estimate the mass of extremely fine roots (less than $1 \mathrm{~cm}$ in length). All living fine roots with a length $>1 \mathrm{~cm}$ separated from each soil sample were scanned (400 dpi resolution). Root lengths and areas were estimated in each sample using WinRHIZO Version Pro V.2009c software (Regent Instruments, QC, Canada). Fine roots were dried for $72 \mathrm{~h}$ at $65{ }^{\circ} \mathrm{C}$ and weighed $( \pm 0.1 \mathrm{mg})$ to estimate specific root length (SRL, length of scanned roots divided by their dry mass) and specific root area (SRA, area of scanned roots divided by their dry mass) in each soil sample. Total root length and total root area in each soil sample were calculated by multiplying the total root dry mass by SRL and SRA, respectively. Soil bulk densities measured in a pit down to a depth of $10 \mathrm{~m}$ in each layer were used to estimate fine root densities per $\mathrm{dm}^{3}$ of soil in each layer. We considered that the soil bulk density was $1.4 \mathrm{~kg} \mathrm{dm}^{-3}$ below a depth of $10 \mathrm{~m}$ (similar to the bulk density in the deepest soil layer sampled). Root Area Index (RAI, expressed in $\mathrm{m}^{2} \mathrm{~m}^{-2}$ ) in each soil layer was calculated multiplying the root area density by the thickness $(\mathrm{m})$ of the soil layer.

\subsection{Leaf sampling}

Total leaf area was determined destructively on eight trees covering the range of basal areas for each genotype, following the same methodology as described in Nouvellon et al. (2010): foliage biomass was determined for each sampled tree by weighing all the leaves in the field and randomly subsampling 30 leaves in each third of the crown (upper, medium and lower). Leaf samples were immediately scanned at $300 \mathrm{dpi}$ resolution and the fresh mass was measured. They were then weighed after oven drying at $65^{\circ} \mathrm{C}$ for $48 \mathrm{~h}$. The dry weights of these subsamples were used in conjunction with their measured area (using the Image software) to calculate specific leaf area (SLA) for each crown section. The foliage dry weight of each crown section was calculated from the foliage fresh weight measured in the field and the water content of the subsamples. The foliage area of each crown section was calculated multiplying the foliage dry weight by the SLA of the subsample. Tree leaf area was obtained by summing the leaf areas of the three crown sections.

Genotype-specific allometric relationships were established $\left(R^{2}>0.90\right)$ and applied to the inventory made at the same date (excluding 3 buffer rows in each plot) to estimate the total leaf area from tree attributes (diameter at breast height and height). LAI was calculated dividing the total leaf area estimated from the allometric relationships by the plot area.

\subsection{Data analyses}

RAI values in each soil layer and for the whole soil profile were compared among the four genotypes using SAS v.9.2 (SAS, Cary, NC, USA). Sampling positions were located close to different trees in each plot, therefore individual fine root measurements within a given soil layer were considered independent. A general linear model was used in a two-way analysis of variance (ANOVA) to test for differences in RAI due to genotypes and blocks. When significant differences were detected among genotypes, the Tukey test was used to compare treatment means. The Bartlett test was used to check homoscedasticity and the normal distribution of the residues was checked using the Shapiro-Wilk test. Mixed-effect models were used to test the effects of genotype, soil depth, sampling position, and interaction genotype $\times$ sampling position, genotype $\times$ soil depth, sampling position $\times$ soil depth as well as genotype $\times$ sampling position $\times$ soil depth (as fixed effects) on fine root diameter, SRL and SRA. Blocks were considered as random effects. Residues were modeled by a first-order autoregressive correlation model to account for the correlations between soil depths. A significance level of $5 \%$ was used in all the analyses. Pearson correlation coefficients were calculated for each genotype between soil depth and root diameter, SRL and SRA at each sampling position.

\section{Results}

\subsection{Fine root distributions}

Seedlings and clones exhibited a similar pattern of deep rooting at age 2 years (Fig. 1). Fine root densities dropped in the topsoil but remained roughly similar between the depths of 0.25 and $6 \mathrm{~m}$ whatever the genotype. Soil water contents at the end of the dry season were similar under the four genotypes down to a depth of $9 \mathrm{~m}$ and much more variable below a depth of $10 \mathrm{~m}$. Distributions of fine root lengths across the soil profiles were roughly similar for the seedlings and the three clones with about $50 \%$ of the total fine root length in the upper $2 \mathrm{~m}$ and less than $5 \%$ of the total fine root length below $8 \mathrm{~m}$ (Fig. 2). Total fine root biomass was genotypedependent, reaching $220 \mathrm{~g} \mathrm{~m}^{-2}$ of soil down to the root front for clone $8,259 \mathrm{~g} \mathrm{~m}^{-2}$ for clone $16,295 \mathrm{~g} \mathrm{~m}^{-2}$ for seedlings and $374 \mathrm{~g} \mathrm{~m}^{-2}$ for clone 14 (Table 3 ). Total fine root length ranged from $3.3 \mathrm{~km}$ per $\mathrm{m}^{2}$ of soil $\left(0.8 \mathrm{~km}\right.$ per $\mathrm{m}^{2}$ of leaf) for clone 8 to $6.0 \mathrm{~km} \mathrm{~m}^{-2}$ of soil ( $2.1 \mathrm{~km}$ per $\mathrm{m}^{2}$ of leaf) for clone 14 .

Vertical tree extensions were almost symmetrical above and belowground for the four studied genotypes (Fig. 3). The ratio between the maximum rooting depth and mean tree height was $1.04,0.83,1.23$ and 0.92 for the seedlings, clone 8 , clone 14 and clone 16 , respectively. The ratios between maximum rooting depth and dominant tree height ranged from 0.74 to 1.10 for the four genotypes (Table 3). The root front reached a depth of $11.5 \mathrm{~m}$ on average for clone 14 (with a very low variability among the 

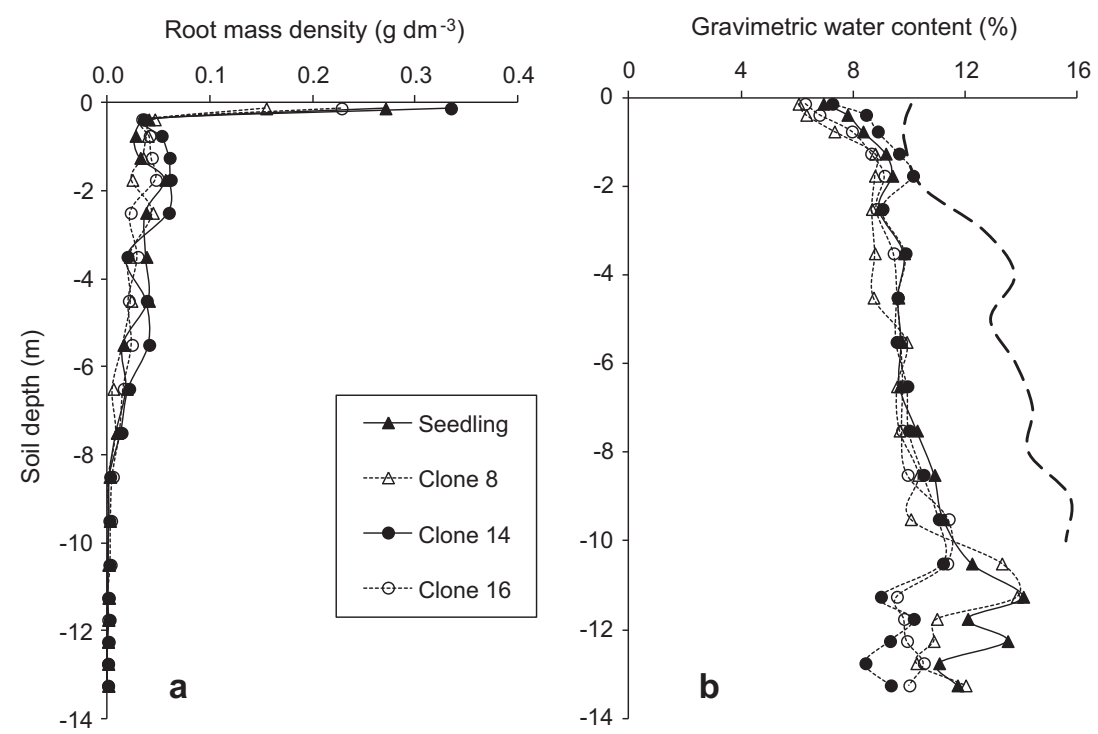

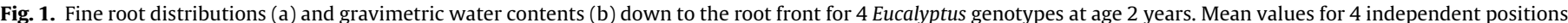

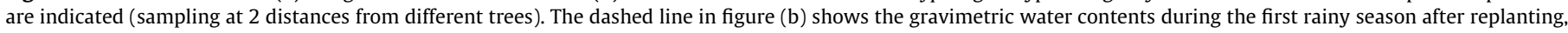
on February 14th 2010.

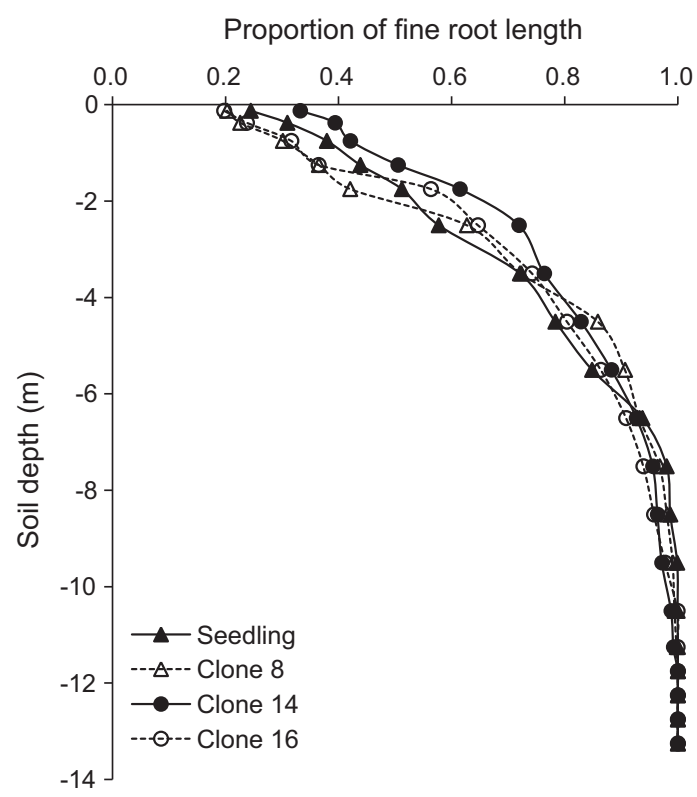

Fig. 2. Cumulated fraction of fine root lengths down to the root front ( $m$ ) at age 2 years for four Eucalyptus genotypes.

sampling positions), and less than $9 \mathrm{~m}$ for the seedlings and clone 8 (with a high variability among the sampling positions). The root front depth was intermediate for clone 16.

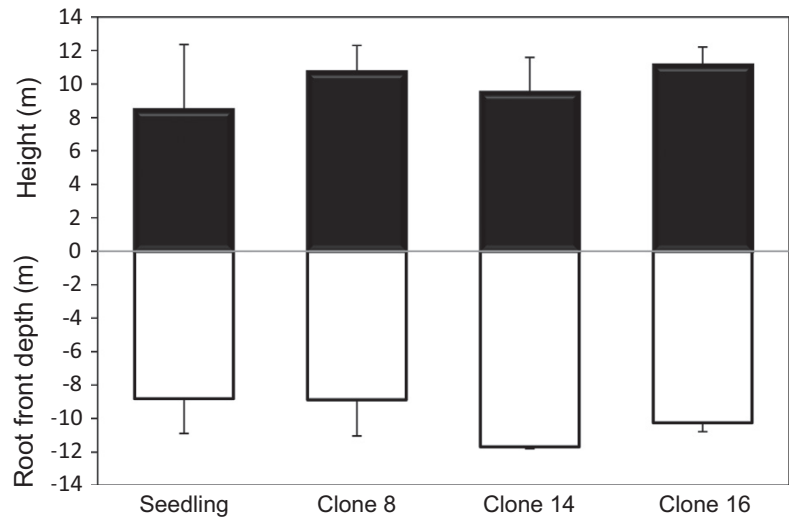

Fig. 3. Mean stand height and root front depth for each Eucalyptus genotype at age 2 years. Vertical bars indicate standard deviations between sampling positions for root front depth $(n=4)$ and trees measured in the inner plots for height $(n=96)$.

\subsection{Fine root traits}

While growth rates were higher for clone 16 than for seedlings (stand basal areas of 11.0 and $8.6 \mathrm{~m}^{2} \mathrm{ha}^{-1}$ at age 2 years, respectively), specific root length (SRL) and specific root area (SRA) were not significantly different between the four genotypes (Fig. 4 and Table 4). By contrast, fine root diameters differed between the genotypes across the sampling depths, with mean values ranging from $0.48 \mathrm{~mm}$ for the seedlings to $0.55 \mathrm{~mm}$ for clone 8 . The

Table 3

Main characteristics of fine roots and leaves for the four genotypes at 2 years of age (the values in blocks 1 and 2 are given between parenthesis).

\begin{tabular}{|c|c|c|c|c|}
\hline & $\begin{array}{l}\text { Seedlings } \\
\text { E. grandis }\end{array}$ & $\begin{array}{l}\text { Clone } 8 \\
\text { E. grandis } \times \text { E. urophylla }\end{array}$ & $\begin{array}{l}\text { Clone } 14 \\
\text { E. saligna }\end{array}$ & $\begin{array}{l}\text { Clone } 16 \\
\text { E. grandis } \times \text { E. camaldulensis }\end{array}$ \\
\hline Root front depth (m) & $8.7(7.9-9.6)$ & $8.9(10.5-7.3)$ & $11.7(11.6-11.8)$ & $10.2(10.5-10.0)$ \\
\hline Leaf area index (LAI, $\mathrm{m}^{2} \mathrm{~m}^{-2}$ ) & $3.4(3.5-3.2)$ & $4.0(3.8-4.1)$ & $2.9(2.8-3.0)$ & $2.8(2.6-3.0)$ \\
\hline Fine root biomass $\left(\mathrm{g} \mathrm{m}^{-2}\right)$ & $295(258-333)$ & $220(216-223)$ & $374(351-396)$ & $259(289-229)$ \\
\hline Root area index (RAI, $\mathrm{m}^{2} \mathrm{~m}^{-2}$ ) & $5.7(6.8-4.5)$ & $4.9(4.8-5.1)$ & $9.3(8.7-9.9)$ & $6.7(6.9-6.5)$ \\
\hline Root length index $\left(\mathrm{km} \mathrm{m}^{-2}\right)$ & $3.6(3.8-3.3)$ & $3.3(2.7-3.9)$ & $6.0(5.6-6.4)$ & $4.6(4.5-4.6)$ \\
\hline Root length/leaf area $\left(\mathrm{km} \mathrm{m}^{-2}\right)$ & $1.1(1.1-1.0)$ & $0.8(0.7-1.0)$ & $2.1(2.0-2.1)$ & $1.6(1.7-1.5)$ \\
\hline RAI/LAI & $1.7(1.9-1.4)$ & $1.3(1.3-1.2)$ & $3.2(3.1-3.3)$ & $2.4(2.7-2.2)$ \\
\hline
\end{tabular}



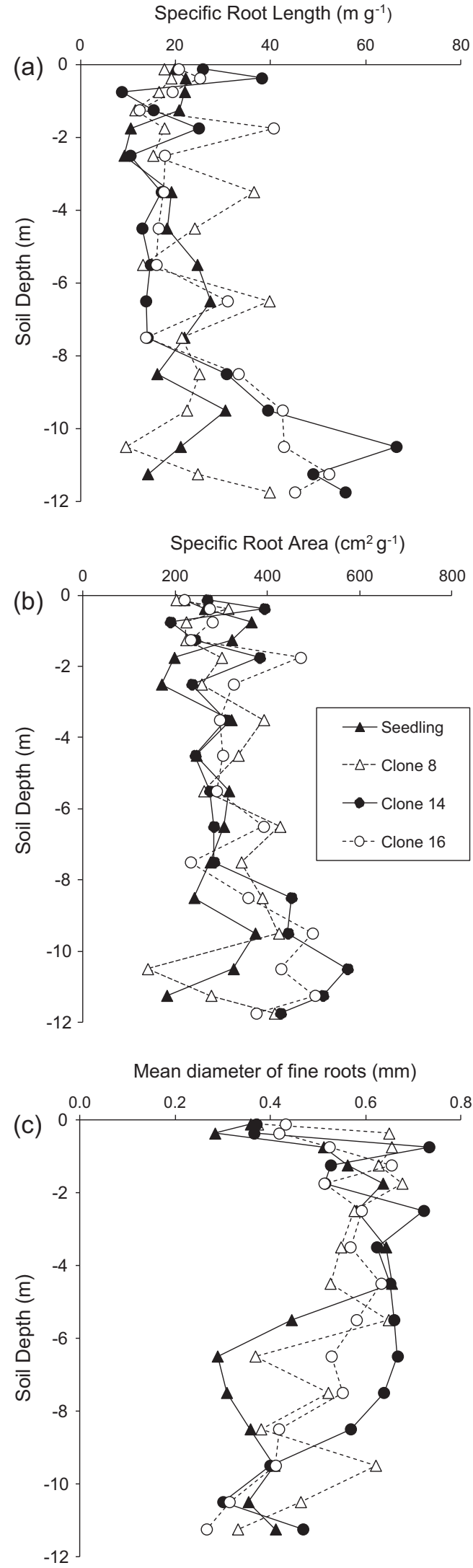

Fig. 4. Changes in specific root length (a), specific root area (b) and mean diameter of fine roots (c) with soil depth for four Eucalyptus genotypes.

sampling depth significantly influenced fine root diameter and SRL but not SRA across the four genotypes (Fig. 4 and Table 4). A positive correlation was found between soil depth and SRL as well as between soil depth and SRA for clones 14 and 16 only ( $R$ between 0.29 and $0.48, P<0.05, n=57-63)$. Regardless the genotype, changes in diameter, SRL and SRA were low between upper and lower soil layers relative to the differences observed between some adjacent soil layers.

Mean values of SRL, SRA and diameter of fine roots across all the soil depths, genotypes and sampling positions were $24 \pm 12 \mathrm{~m} \mathrm{~g}^{-1}$, $318 \pm 90 \mathrm{~cm}^{2} \mathrm{~g}^{-1}$ and $0.5 \pm 0.1 \mathrm{~mm}$, respectively. However, the variability was high. SRL ranged from 9 to $66 \mathrm{~m} \mathrm{~g}^{-1}$, SRA from 140 to $573 \mathrm{~cm}^{2} \mathrm{~g}^{-1}$ and mean root diameter from 0.3 to $0.7 \mathrm{~mm}$ depending on the soil layer and the genotype.

\subsection{Relationship between leaf area index and root area index}

While total RAI reached $9.3 \mathrm{~m}^{2} \mathrm{~m}^{-2}$ for clone 14 (Table 3), it was significantly lower for clone $8\left(4.9 \mathrm{~m}^{2} \mathrm{~m}^{-2}\right)$ and intermediate for seedlings $\left(5.7 \mathrm{~m}^{2} \mathrm{~m}^{-2}\right)$ and clone $16\left(6.7 \mathrm{~m}^{2} \mathrm{~m}^{-2}\right)$. RAI was significantly higher in the $1-3 \mathrm{~m}$ soil layer for clone 14 $\left(3.2 \mathrm{~m}^{2} \mathrm{~m}^{-2}\right)$ than for seedlings $\left(1.2 \mathrm{~m}^{2} \mathrm{~m}^{-2}\right)$ and, although differences were not significant, the trend was similar in soil layers 0 $1 \mathrm{~m}$ and $>5 \mathrm{~m}$ (Fig. 5). The RAI/LAI ratio ranged from 3.2 for clone 14 to 1.3 for clone 8 with a strong negative relationship between the ratio of root area to leaf area and LAI across the four genotypes in the two blocks (Fig. 6). The ratio of root length to leaf area ranged from 0.8 for the genotype with the highest LAI to $1.6-2.1$ for the genotypes with the lowest LAI (Table 3).

\section{Discussion}

\subsection{Exploration of deep soil layers}

The fine roots of the four genotypes explored a huge soil volume 2 years after planting. Similar soil water contents at the end of the dry season under the four genotypes suggested that the clones and the seedlings had the same capacity to withdraw soil water down to a depth of $9 \mathrm{~m}$. Soil water contents were much more variable below a depth of $10 \mathrm{~m}$, which might reflect a deeper uptake of soil water for certain genotypes and/or slight differences in soil texture for very deep soil layers. Piezometers in the same stand showed that the water table was at a depth of $14-15 \mathrm{~m}$ at the sampling age. Fine root densities sharply decreased below the upper layer $(0-0.25 \mathrm{~m})$, as commonly reported in forest ecosystems (Schenk and Jackson, 2002b). The pattern below the depth of $0.25 \mathrm{~m}$ was by contrast uncommon in our study, with fine root densities roughly constant down to a depth of $6 \mathrm{~m}$ for the four genotypes. While models commonly consider an exponential decrease in fine root densities with soil depth in forest ecosystems (Schenk and Jackson, 2002b), soils were also explored homogeneously by fine roots down to depths of more than $3 \mathrm{~m}$ at the peak of leaf area index (2 years after planting) in eucalypt plantations in Congo and Brazil (Bouillet et al., 2002; Laclau et al., 2013a). This pattern might be explained by a high water demand of eucalypt trees requiring the withdrawal of large amounts of water stored after clear-cutting in deep soil layers. A concentration of fine roots in the upper soil layers commonly observed close to the harvest age in these fast-growing plantations might reflect the nutrient inputs in the topsoil through the biological cycle (Laclau et al., 2010).

Although the sampling intensity was low in the topsoil in our experiment (only four sampling positions for each genotype) relative to most of root studies in forest ecosystems, the results confirm that an accurate sampling of deep soil layers is a priority in 2-year-old eucalypt plantations established in Ferralsol soils. Indeed, fine roots in the $0-0.5 \mathrm{~m}$ soil layer accounted for only $23-39 \%$ of the total fine root length down to the root front for the four genotypes. An exceptional sampling effort in deep soil 
Table 4

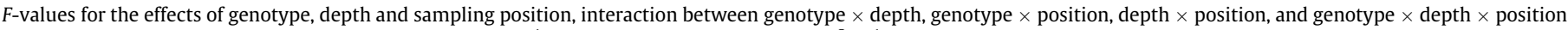
on fine root diameter $(\mathrm{mm})$, specific root length (SRL, $\mathrm{m} \mathrm{g}^{-1}$ ), and specific root area (SRA, $\mathrm{cm}^{2} \mathrm{~g}^{-1}$ ).

\begin{tabular}{|c|c|c|c|}
\hline & Diameter & SRL & SRA \\
\hline Genotype & $F_{3,91}=3.36^{*}$ & $F_{3,100}=1.35$ & $F_{3,100}=1.54$ \\
\hline Depth & $F_{15,91}=5.46^{* *}$ & $F_{15,100}=1.80$ & $F_{15,100}=1.35$ \\
\hline Position & $F_{1,91}=0.00$ & $F_{1,100}=0.25$ & $F_{1,100}=1.73$ \\
\hline Genotype $\times$ Depth & $F_{42,91}=1.37$ & $F_{44,100}=0.79$ & $F_{44,100}=0.61$ \\
\hline Genotype $\times$ Position & $F_{3,91}=0.60$ & $F_{3,100}=1.26$ & $F_{3,100}=2.18$ \\
\hline Position $\times$ Depth & $F_{14,91}=1.05$ & $F_{15,100}=0.72$ & $F_{15,100}=0.72$ \\
\hline Genotype $\times$ Depth $\times$ Position & $F_{35,91}=1.69$ & $F_{38,100}=0.48$ & $F_{38,100}=0.49$ \\
\hline
\end{tabular}

* Significant effects at $P<0.05$

** Significant effects at $P<0.01$.

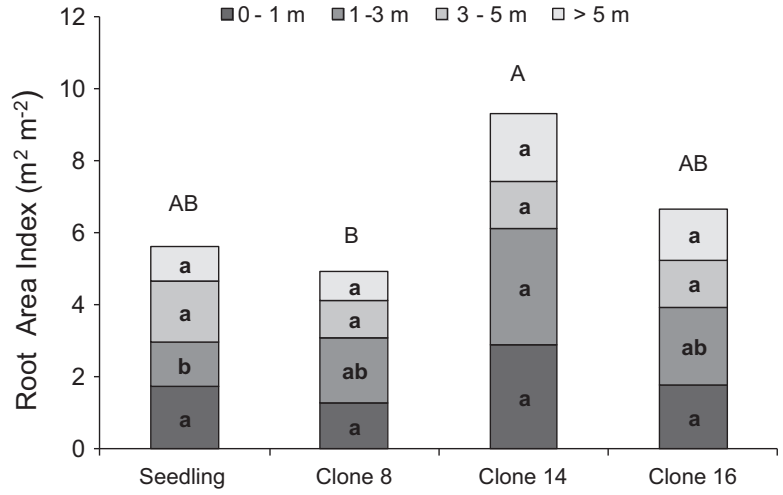

Fig. 5. Root area index in the $0-1 \mathrm{~m}, 1-3 \mathrm{~m}, 3-5 \mathrm{~m}$ and $>5 \mathrm{~m}$ soil layers $\left(\mathrm{m}^{2} \mathrm{~m}^{-2}\right)$ for each Eucalyptus genotype. Different lower-case letters in the same soil layer indicate significant differences between genotypes $(P<0.05)$. Different upper-case letters indicate significant differences between genotypes for the total root area index down to the root front.

layers was therefore more relevant than a high sampling intensity in the topsoil to accurately estimate total fine root biomass, fine root length and fine root area. Although fine root densities were significantly higher close to trees than at mid inter-row in our study, the absolute differences between the two sampling positions were low (data not shown). Other studies suggest that the spatial variability in the upper soil layers is relatively low in tropical eucalypt plantations and that soil layers at depths $>1 \mathrm{~m}$ contain a large share of the total fine root biomass (Bouillet et al., 2002; Laclau et al., 2013a,b).

Contrary to our first hypothesis, the genotypes with the highest growth rates did not exhibit higher SRL and SRA values than the genotypes with the slowest growth rates. This pattern might be a result of the low differences in growth rates between the four studied genotypes that were selected for their high biomass production. The effect of soil depth on fine root diameter, SRL and SRA was genotype-dependent with relatively low differences between the topsoil and the deepest soil layers. A small effect of soil depth on fine root diameter, SRL and SRA was also shown recently down to the root front (at a depth of 7-8 m) for Citrus trees in Brazil (Adriano, 2015). Minirhizotrons monitored over 2 years from the topsoil to a depth of $6 \mathrm{~m}$ in a nearby $E$. grandis plantation showed that peaks of fine root growth occurred at different dates depending on the soil depth (Lambais, 2015). Different stages of fine root development at the date of root sampling in our study might account for the significant differences in diameter and SRL observed between the soil layers. Morphological and chemical root traits compared in the topsoil and in the $1.0-1.5 \mathrm{~m}$ soil layer (or in the deepest soil layer when soils were shallower) in 20 plant communities located across three climatic zones (tropical, mediterranean and montane) suggested that soil depth influenced some
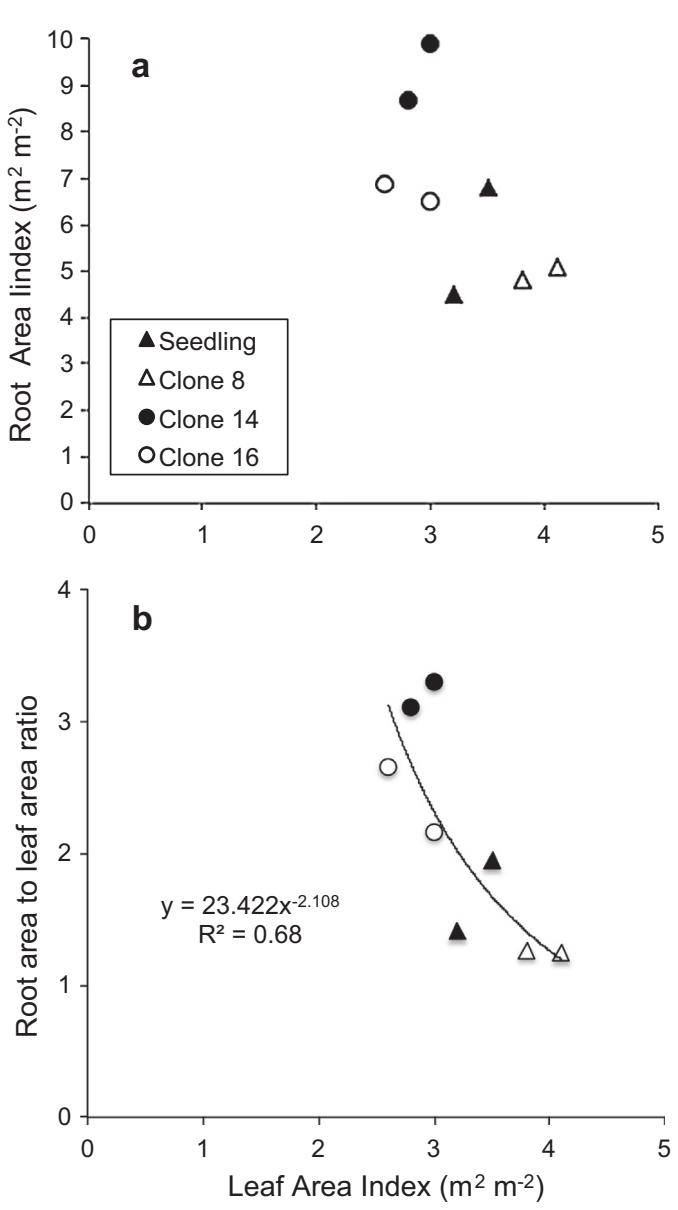

Fig. 6. Relationship between root area index $\left(\mathrm{m}^{2} \mathrm{~m}^{-2}\right)$ and leaf area index $\left(\mathrm{m}^{2} \mathrm{~m}^{-2}\right)$ (a) and between the root area: leaf area ratio and LAI (b), across the 4 Eucalyptus genotypes at age 2 years. Mean values per plot in each block are shown.

root functions. Shallow, fine roots were thinner, richer in nitrogen and with lower lignin concentrations compared to deep fine roots. However, absolute differences were small for most of the traits measured and SRL values were not statistically different between shallow and deep soil layers (Prieto et al., 2015). SRL values in our study were within the range reported in E. grandis plantations sampled at different ages and in soil of contrasting fertility (Maurice et al., 2010). While fine root diameter, SRL and SRA were of the same order of magnitude for the four genotypes, fine root biomass was highly variable (from 220 to $374 \mathrm{~g} \mathrm{~m}^{-2}$ at age 2 years). This pattern suggests that tree breeding aiming to reduce the metabolic cost of soil exploration should focus on root biomass rather than on fine root traits like SRL or SRA in tropical eucalypt plantations. 


\subsection{Relationship between mean stand height and root front depth}

In agreement with our second hypothesis, the vertical tree extension above and belowground was almost symmetrical for the four genotypes, irrespective of the propagation technique (seeds or cuttings). The depth of the root front shown by soil coring for each genotype was consistent with soil water content profiles across the soil layers. Indeed, soil water contents between the depths of $10 \mathrm{~m}$ and $13.5 \mathrm{~m}$ were higher under seedlings and clone 8 than under clones 14 and 16 , which suggests that clones 14 and 16 withdrew water more deeply than seedlings and clone 8 . However, the variability in soil water contents below a depth of $10 \mathrm{~m}$ may also reflect small differences in soil texture between the plots. Fine roots below a depth of $8 \mathrm{~m}$ amounted to less than $5 \%$ of the total fine root biomass whatever the genotype in our study, which was consistent with previous results for E. grandis seedlings in Brazil (Christina et al., 2011; Laclau et al., 2013a). A recent study using time series of soil water contents and measurements of water table level over five years to parameterize a process-based model showed that very low densities of $E$. grandis fine roots at depths $>10 \mathrm{~m}$ can provide most of tree water requirements during dry periods after canopy closure (Christina, 2015). The role of the deepest roots, even though their density is extremely low, can therefore mostly explain the behavior of eucalypt trees during drought events. The variability in root front depth observed in our study (between 8 and $11.5 \mathrm{~m}$ for 2-year-old trees) suggests that this trait might be interesting to measure before planting new clones at large scale in drought prone regions. Indeed, a fast access to large amounts of water stored in very deep soil layers after the harvest of the previous stand might contribute to improving the survival rates during exceptional droughts of eucalypt trees growing in very deep soils.

\subsection{Root length and root area relative to leaf area in Eucalyptus plantations}

A wide range of RAI has been reported in forest ecosystems and, as far as we are aware, our study is the first showing the proportions of RAI in each soil layer down to the root front in tropical planted forests. RAI values between 5 and $9 \mathrm{~m}^{2} \mathrm{~m}^{-2}$ for our four genotypes were close to mean values of $6-7 \mathrm{~m}^{2} \mathrm{~m}^{-2}$ reported by Jackson et al. (1997) for tropical forests. A large share of total RAI (34-47\% depending on the genotype) was found below a depth of $3 \mathrm{~m}$ in our 2-year-old stands, which highlights the need to sample very deep soil layers to accurately estimate the potential of water uptake of Eucalyptus genotypes in deep soils. Despite the fast growth of the four studied genotypes and a high water demand with LAI values of $3-4 \mathrm{~m}^{2} \mathrm{~m}^{-2}$ at age 2 years, higher RAI values have been reported in temperate forests (Jackson et al., 1997; Meinen et al., 2009) and in orange orchards (Adriano, 2015).

In agreement with our third hypothesis, the root area/leaf area ratio was negatively correlated with LAI. Although the predictive value of the relationship is probably weak as a result of the dependency of the variables (both contain a leaf area term in the figure), this trend is in agreement with previous studies. Comparing nine Eucalyptus species from a biodiversity hotspot, Hamer et al. (2015) showed that the species from the wetter regions had a lower root length to leaf area ratio than those from drier environments, when they were grown in the same experimental conditions. Similarly, Costa e Silva et al. (2004) showed that a drought resistant $E$. globulus clone had a higher root area to leaf area ratio and root length to leaf area ratio than a drought sensitive clone, especially under water-limited conditions. This pattern suggests that genotypes with the highest LAI (presumably genotypes from wet environments) could have the lowest root length/leaf area and root area/leaf area ratios when they are growing under the same environment, which is consistent with our results. However, we must be cautious because we are not sure that the genotypes with the lowest LAI in our study are the most adapted to drought, except clone 16 (E. camaldulensis hybrid selected in a dry region), which has indeed a low LAI and a high RAI/LAI ratio. A wide diversity of mechanisms have been shown within the Eucalyptus genus to cope with water restriction (White et al., 2000; Whitehead and Beadle, 2004). Depending on the species, structural adaptations maintaining homeostasis in water use can involve primarily a limitation of water loss through a reduction in leaf area (Pita and Pardos, 2001) or an increase in root area in deep soil layers to maximize water uptake (Dye, 1996). Further studies are needed to assess whether the decrease in RAI/LAI ratio when LAI increases is a general strategy of Eucalyptus trees to maintain homeostasis in water use or only valid for the four genotypes studied here.

A high diversity of form and function among fine-root orders suggests that the traditional definition of fine roots as all roots $\leqslant 2 \mathrm{~mm}$ in diameter may be unable to account for the root area of water capture (Pregitzer et al., 2002; McCormack et al., 2015). A study carried out in three Sitka spruce (Picea sitchensis) stands to compare RAI estimated for all the fine roots (diameter $<2 \mathrm{~mm}$ as in our study) with the absorbing root area ( $\mathrm{RAI}_{\mathrm{absorbing}}$ ) estimated using electrical impedance measurements showed that $\mathrm{RAI}_{\text {absorbing }}$ was not proportional to the total fine root area and accounted for only $4-20 \%$ of the total RAI. Contrary to RAI for all the fine roots, $\mathrm{RAI}_{\mathrm{absorbing}}$ was proportional to the basal area across the three studied stands, which also suggested that only a fraction of total RAI was responsible for tree water uptake (Butler et al., 2010).

In conclusion, our study shows a fast exploration of deep soil layers by fine roots for the most productive clones and seedlings in Brazilian Eucalyptus plantations, with a depth of the root front corresponding roughly to mean stand height. This relationship between tree height and root front depth is probably only valid in absence of any physical or chemical barrier in the soil. A variability in root front depth between $8 \mathrm{~m}$ and $11.5 \mathrm{~m}$ depending on the genotype suggests that the velocity of root front movement downward might be an interesting criterion to consider before planting new clones at large scale, sampling soil cores down to depths of $10-15 \mathrm{~m}$ under the most promising genotypes between 1 and 2 years after the establishment of the clonal tests. The large variability in fine root biomass between the four genotypes in our study suggests that the carbon allocation patterns between aboveand below-ground tree components may largely differ depending on the genotype. The belowground behavior of eucalypt trees deserves more attention to select the most adapted genotypes in a context of increasing abiotic stresses. Clones combining a high velocity of root front movement downward with high SRL values might be of interest to access to large amounts of water stored in deep soil layers before canopy closure.

\section{Acknowledgements}

We thank Eder Araujo da Silva (Floragro) and his employees, Rildo Moreira e Moreira and the staff of the Itatinga Research Station (ESALQ/USP) for their technical support. Rafael C. Pinheiro was funded by the São Paulo Research Foundation (FAPESP, project 2012/13380-3). The Eucflux project is funded by Brazilian forestry companies (ArcelorMittal, Cenibra, Bahia Specialty Cellulose, Duratex, Fibria, International Paper, Klabin, Suzano, and Vallourec), CIRAD and North Carolina State University. We also acknowledge the French Agence Nationale de la Recherche for its support through the MACACC (Modelling to ACCompany stakeholders towards Adaptation of forestry and agroforestry systems to Climate changes) project (ANR- 13-AGRO-0005, AGROBIOSPHERE program). 


\section{References}

ABRAF, 2006. Anuário Estatístico da ABRAF 2006: ano base 2005. Associação Brasileira de Produtores de Florestas Plantadas, Brasília, p. 80.

Adriano, E., 2015. Distribuição de raízes e a relação com o estado hídrico de laranjeira 'Valencia' enxertada sobre limoeiro 'Cravo'. PhD thesis, Universidade Estadual Paulista 'Júlio de Mesquita Filho', Botucatu, Brazil, 61pp.

Akkermans, T., Lauwaet, D., Demuzere, M., Vogel, G., Nouvellon, Y., Ardö, J., Caquet, B., De Grandcourt, A., Merbold, L., Kutsch, W., Van Lipzig, N., 2012. Validation and comparison of two soil-vegetation-atmosphere transfer models for tropical Africa. J. Geophys. Res. 117 (G02).

Al Afas, N., Marron, N., Zavalloni, C., Ceulemans, R., 2008. Growth and production of a short-rotation coppice culture of poplar - IV: Fine root characteristics of five poplar clones. Biomass Bioenergy 32 (6), 494-502.

Battie-Laclau, P., Laclau, J.P., Domec, J.C., Christina, M., Bouillet, J.P., Piccolo, M.C., Gonçalves, J.L.M., Moreira, R.M., Krusche, A.V., Bouvet, J.M., Nouvellon, Y., 2014 Effects of potassium and sodium supply on drought-adaptive mechanisms in Eucalyptus grandis plantations. New Phytol. 203 (2), 401-413.

Binkley, D., 2015. Ecosystems in four dimensions. New Phytol. 206 (3), 883-885.

Booth, T.H., 2013. Eucalypt plantations and climate change. For. Ecol. Manage. 301 $28-34$.

Bonneu, A., Dumont, Y., Rey, H., Jourdan, C., Fourcaud, T., 2012. A minimal continuous model for simulating growth and development of plant root systems. Plant Soil 354 (1-2), 211-227.

Bouillet, J.P., Laclau, J.P., Arnaud, M., Thongo, A., 2002. Changes with age in the spatial distribution of roots of a Eucalyptus clone in the Congo. Impact on water and nutrient uptake ability. For. Ecol. Manage. 171 (1-2), 43-57.

Butler, A.J., Barbier, N., Cermák, J., Koller, J., Thornily, C., McEvoy, C., Nicoll, B., Perks, M.P., Grace, J., Meir, P., 2010. Estimates and relationships between aboveground and belowground resource exchange surface areas in a Sitka spruce managed forest. Tree Physiol. 30 (6), 705-714.

Christina, M., Laclau, J.P., Gonçalves, J.L.M., Jourdan, C., Nouvellon, Y., Bouillet, J.P., 2011. Almost symmetrical vertical growth rates above and below ground in one of the world's most productive forests. Ecosphere 2 (3). http://dx.doi.org 10.1890/ES10-00158.1, art27.

Christina, M., 2015. Modeling the Water-Carbon Cycles at Tree Scale in Eucalyptus Plantations Under Contrasting Water and Nutrient Constraints. PhD thesis, SupAgro Montpellier, Montpellier, France.

Christoffersen, B.O., Restrepo-Coupea, N., Arain, M.A., Baker, I.T., Cestaro, B.P., Ciais P., Fisher, J.B., Galbraith, D., et al., 2014. Mechanisms of water supply and vegetation demand govern the seasonality and magnitude of evapotranspiration in Amazonia and Cerrado. Agric. For. Meteorol. 191, 33-50.

Costa e Silva, F., Shvaleva, A., Maroco, J.P., Almeida, M.H., Chaves, M.M., Pereira, J.P., 2004. Responses to water stress in two Eucalyptus globulus clones differing in drought tolerance. Tree Physiol. 24 (10), 1165-1172.

Decker, M., Pitman, A.J., Evans, J.P., 2013. Groundwater constraints on simulated transpiration variability over Southeastern Australian forests. J. Hydrom. 14 (2), 543-559.

du Toit, B., Smith, C.W., Little, K.M., Boreham, G., Pallett, R.N., 2010. Intensive, sitespecific silviculture: manipulating resource availability at establishment for improved stand productivity. A review of South African research. For. Ecol. Manage. 259 (9), 1836-1845.

Dye, P.J., 1996. Response of Eucalyptus grandis trees to soil water deficits. Tree Physiol. 16, 233-238.

Fensham, R.J., Fairfax, R.J., 2007. Drought-related tree death of savanna eucalypts: species susceptibility, soil conditions and root architecture. J. Veg. Sci. 18 (1), 71-80.

Freycon, V., Wonkam, C., Fayolles, A., Laclau, J.P., Lucot, E., Jourdan, C., Cornu, G. Gourlet-Fleury, S., 2015. Tree roots can penetrate deeply in African semideciduous rain forests: evidence from two common soil types. J. Trop. Ecol. 31 (1), 13-23.

Grant, J.D., Nichols, J.D., Yao, R.L., Smith, R.G.B., Brennan, P.D., Vanklay, J.K., 2012 Depth distribution of roots of Eucalyptus dunnii and Corymbia citriodora subsp. variegata in different soil conditions. For. Ecol. Manage. 269, 249-258.

Hamer, J.J., Veneklaas, E.J., Renton, M., Poot, P., 2015. Links between soil texture and root architecture of Eucalyptus species may limit distribution ranges under future climates. Plant Soil. http://dx.doi.org/10.1007/s11104-015-2559-5, online.

Harper, R.J., Smettem, K.R.J., Carter, J.O., McGrath, J.F., 2009. Drought deaths in Eucalyptus globulus (Labill.) plantations in relation to soils, geomorphology and climate. Plant Soil 324 (1), 199-207.

Harper, R.J., Sochacki, S.J., Smettem, K.R.J., Robinson, N., 2014. Managing water in agricultural landscapes with short-rotation biomass plantations. GCB Bioenergy 6 (5), 544-555.

IBÁ, 2015. Report. Indústria Brasileira de Árvores - Brazilian Tree Industry. Brasília, 64pp. <http://www.iba.org/en/resources/publications> (access 10.11.15).

Iversen, C.M., 2010. Digging deeper: fine-root responses to rising atmospheric CO2 concentration in forested ecosystems. New Phytol. 186 (2), 346-357.

Jackson, R.B., Mooney, H.A., Schulze, E.D., 1997. A global budget for fine root biomass, surface area, and nutrient contents. Proc. Natl. Acad. Sci. 94 (14), $7362-7366$.

Jo, I., Fridley, J.D., Frank, D.A., 2015. Linking above- and belowground resource use strategies for native and invasive species of temperate deciduous forests. Biol. Inv. 17 (5), 1545-1554.
Laclau, J.-P., Bouillet, J.-P., Gonçalves, J.L.M., Silva, E.V., Jourdan, C., Cunha, M.C.S., Moreira, M.R., Saint-André, L., Maquère, V., Nouvellon, Y., Ranger, J., 2008. Mixed-species plantations of Acacia mangium and Eucalyptus grandis in Brazil. 1. Biomass allocation and net primary production. For. Ecol. Manage. 255, 3905-3917.

Laclau, J.-P., Ranger, J., Gonçalves, J.L.M., Maquère, V., Krushe, A.V., Thongo M’Bou, A., Nouvellon, Y., Saint-André, L., Bouillet, J.-P., Piccolo, M.C., Deleporte, P., 2010. Biogeochemical cycles of nutrients in tropical Eucalyptus plantations. Main features shown by intensive monitoring in Congo and Brazil. For. Ecol. Manage. 259 (9), 1771-1785.

Laclau, J.-P., da Silva, E.A., Lambais, G.R., Bernoux, M., le Maire, G., Stape, J.L., Bouillet, J.-P., Gonçalves, J.L.M., Jourdan, C., Nouvellon, Y., 2013a. Dynamics of soil exploration by fine roots down to a depth of $10 \mathrm{~m}$ throughout the entire rotation in Eucalyptus grandis plantations. Front. Plant Sci. 4, 243.

Laclau, J.-P., Nouvellon, Y., Reine, C., Gonçalves, J.L.M., Krushe, A.V., Jourdan, C., le Maire, G., Bouillet, J.-P., 2013b. Mixing Eucalyptus grandis and Acacia mangium trees leads to transgressive fine root over-yielding and exclusion of the weakest competitor from resource-rich soil layers. Oecologia 172, 903-913.

Lambais, G.R., 2015. Produção e mortalidade de raízes finas de Eucalyptus grandis cultivados em Latossolos (Itatinga-SP). PhD thesis, Center for Nuclear Energy in Agriculture (CENA), University of São Paulo, Piracicaba, Brazil.

Mackay, D.S., Roberts, D.E., Ewers, B.E., Sperry, J.S., McDowell, N.G., Pockman, W.T., 2015. Interdependence of chronic hydraulic dysfunction and canopy processes can improve integrated models of tree response to drought. Water Resour. Res. 51 (8), 6156-6176.

Maeght, J.L., Rewald, B., Pierret, A., 2013. How to study deep roots - and why it matters. Front. Plant Sci. 4, 299.

Magnani, F., Grace, J., Borghetti, M., 2002. Adjustment of tree structure in response to the environment under hydraulic constraints. Funct. Ecol. 16 (3), 385-393.

Maquère, V., 2008. Dynamics of Mineral Elements Under a Fast-Growing Eucalyptus Plantation in Brazil. Implications for Soil Sustainability. PhD Thesis, AgroParisTech, Paris, France.

Mareschal, L., Laclau, J.-P., Nzila, J.D.D., Versini, A., Koutika, L.S., Mazoumbou, J.-C., Deleporte, P., Bouillet, J.-P., Ranger, J., 2013. Nutrient leaching and deep drainage under Eucalyptus plantations managed in short rotations after afforestation of an African savanna: two 7-year time series. For. Ecol. Manage. $307,242-254$.

Martin-StPaul, N.K., Limousin, J.M., Vogt-Schilb, H., Rodriguez-Calcerrada, J., Rambal, S., Longepierre, D., Misson, L., 2013. The temporal response to drought in a Mediterranean evergreen tree: comparing a regional precipitation gradient and a throughfall exclusion experiment. Glob. Change Biol. 19 (8), 2413-2426.

Matusick, G., Ruthrof, K.X., Brouwers, N.C., Dell, B., Hardy, G.S.J., 2013. Sudden forest canopy collapse corresponding with extreme drought and heat in a mediterranean-type eucalypt forest in southwestern Australia. Eur. J. Forest Res. 132 (3), 497-510.

Maurice, J., Laclau, J.P., Re, D.S., Gonçalves, J.L.M., Nouvellon, Y., Bouillet, J.P., Stape, J. L., Ranger, J., Behling, M., Chopart, J.L., 2010. Fine root isotropy in Eucalyptus grandis plantations. Towards the prediction of root length densities from root counts on trench walls. Plant Soil 334 (1), 261-275.

McCormack, M.L., Dickie, I.A., Eissenstat, D.M., Fahey, T.J., Fernandez, C.W., Guo, D., Helmisaari, H.S., Hobbie, E.A., Iversen, C.M., Jackson, R.B., LeppälammiKujansuu, J., Norby, R.J., Phillips, R.P., Pregitzer, K.S., Pritchard, S.G., Rewald, B., Zadworny, M., 2015. Redefining fine roots improves understanding of belowground contributions to terrestrial biosphere processes. New Phytol. 207 (3), 505-518.

Meinen, C., Hertel, D., Leuschner, C., 2009. Biomass and morphology of fine roots in temperate broad-leaved forests differing in tree species diversity: is there evidence of below-ground overyielding? Oecologia 161 (1), 99-111.

Mendham, D.S., White, D.A., Battaglia, M., McGrath, J.F., Short, T.M., Ogden, G.N., Kinal, J., 2011. Soil water depletion and replenishment during first- and early second-rotation Eucalyptus globulus plantations with deep soil profiles. Agric. For. Meteorol. 151 (12), 1568-1579.

Nepstad, D.C., Carvalho, C.R., Davidson, E.A., Jipp, P.H., Lefebvre, P.A., Negreiros, G.H., Silva, E.D., Stone, T.A., Trumbore, S.E. Vieira, S., 1994. The role of deep roots in the hydrological and carbon cycles of Amazonian forests and pastures. Nature 372 (6507), 666-669.

Nibau, C., Gibbs, D.J., Coates, J.C., 2008. Branching out in new directions: the control of root architecture by lateral root formation. New Phytol. 179 (3), 595-614.

Nouvellon, Y., Laclau, J.-P., Epron, D., Kinana, A., Mabiala, A., Roupsard, O., Bonnefond, J.M., le Maire, G. Marsden, C., Bontemps, J.D., Saint-André, L., 2010. Within-stand and seasonal variations of specific leaf area in a clonal Eucalyptus plantation in the Republic of Congo. For. Ecol. Manage. 259 (9), 1796-1807.

O'Grady, A.P., Worledge, D., Battaglia, M., 2006. Above- and below-ground relationships, with particular reference to fine roots, in a young Eucalyptus globulus (Labill.) stand in southern Tasmania. Trees 20 (5), 531-538.

Ostonen, I., Püttsepp, Ü., Biel, C., Alberton, O., Bakker, M.R., Lõhmus, K., Majdi, H., Metcalfe, D., Olsthoorn, A.F.M., Pronk, A., Vanguelova, E., Weih, M., Brunner, I., 2007. Specific root length as an indicator of environmental change. Plant Biosyst. 141 (3), 426-442.

Pita, P., Pardos, J.A., 2001. Growth, leaf morphology, water use and tissue water relations of Eucalyptus globulus clones in response to water deficit. Tree Physiol. 21 (9), 599-607. 
Poot, P., Veneklaas, E.J., 2013. Species distribution and crown decline are associated with contrasting water relations in four common sympatric eucalypt species in southwestern Australia. Plant Soil 364 (1), 409-423.

Pregitzer, K.S., DeForest, J.L., Burton, A.J., Allen, M.F., Ruess, R.W., Hendrick, R.L., 2002. Fine root architecture of nine North American trees. Ecol. Monogr. 72 (2), 293-309.

Prieto, I., Roumet, C., Cardinael, R., Dupraz, C., Jourdan, C., Kim, J.H., Maeght, J.L., Mao, Z., Pierret, A., Portillo, N., Roupsard, O., Thammahacksa, C., Stokes, A., 2015. Root functional parameters along a land-use gradient: evidence of a community-level economics spectrum. J. Ecol. 103 (2), 361-373.

Reich, P.B., 2014. The world-wide 'fast-slow' plant economics spectrum: a traits manifesto. J. Ecol. 102 (2), 275-301.

Rhizopoulou, S., Davies, W.J., 1993. Leaf and root growth dynamics in Eucalyptus globulus seedlings grown in drying soil. Trees $8(1), 1-8$.

Robinson, N., Harper, R.J., Smettem, K.R.J., 2006. Soil water depletion by Eucalyptus spp. integrated into dryland agricultural systems. Plant Soil 286 (1), 141-151.

Roupsard, O., Ferhi, A., Granier, A., Pallo, F., Depommier, D., Mallet, B., Joly, H.I. Dreyer, E., 1999. Reverse phenology and dry-season water uptake by Faidherbia albida (Del.) A. Chev. in an agroforestry parkland of Sudanese west Africa. Funct. Ecol. 13 (4), 460-472.

Schenk, H.J., Jackson, R.B., 2002a. Rooting depths, lateral root spreads and belowground/above-ground allometries of plants in water-limited ecosystems. J. Ecol. 90 (3), 480-494.
Schenk, H.J., Jackson, R.B., 2002b. The global biogeography of roots. Ecol. Monogr. 72 (3), 311-328.

Stape, J.L., Binkley, D., Ryan, M.G., Fonseca, S., Loos, R.A., Takahashi, E.N., Silva, C.R. Silva, S.R.F., Hakamada, R.E., Ferreira, J.M.A., Lima, A.M.N., Gava, J.L., Leite, F.P., Andrade, H.B., Alves, J.M., Silva, G.G.C., Azevedo, M.R., 2010. The Brazil Eucalyptus potential productivity project: influence of water, nutrients and stand uniformity on wood production. For. Ecol. Manage. 259 (9), 1684-1694.

van Raij, B., Andrade, J.C., Cantarella, H., Quaggio, J.A., 2001. Análise química para avaliação da fertilidade de solos tropicais. Instituto Agronômico, Campinas, p. 285.

Versini, A., Mareschal, L., Matsoumbou, T., Zeller, B., Ranger, J., Laclau, J.-P., 2014 Effects of litter manipulation in a tropical Eucalyptus plantation on leaching of mineral nutrients, dissolved organic nitrogen and dissolved organic carbon. Geoderma 232-234, 426-436.

White, D.A., Turner, N.C., Galbraith, J.H., 2000. Leaf water relations and stomata behavior of four allopatric Eucalyptus species planted in Mediterranean southwestern Australia. Tree Physiol. 20 (17), 1157-1165.

Whitehead, D., Beadle, C.L., 2004. Physiological regulation of productivity and water use in Eucalyptus: a review. For. Ecol. Manage. 193, 113-140.

Zeppel, M., 2013. Convergence of tree water use and hydraulic architecture in water-limited regions: a review and synthesis. Ecohydrology 6 (5), 889-900.

Zolfaghar, S., Villalobos-Vega, R., Cleverly, J., Zeppel, M., Rumman, R., Eamus, D. 2014. The influence of depth-to-groundwater on structure and productivity of Eucalyptus woodlands. Aust. J. Bot. 62 (5), 428-437. 